\title{
Androgen Receptor Antagonists and Anti-prostate Cancer Activities of Some Synthesized Steroidal Candidates
}

\author{
Saleh Abd El-Rahman Bahashwan, ${ }^{a}$ Mohamed Abd El-Rahman Al-Omar, ${ }^{b}$ Essam Ezzeldin, ${ }^{c}$ \\ Mohamed Mostafa Abdalla, ${ }^{d}$ Ahmed Abd El-Hameed FAYED, ${ }^{a}$ and Abdel-Galil El-Sayed AmR ${ }^{*}, e, f$ \\ ${ }^{a}$ Department of Pharmacy, College of Health Science, Taibah University; Madinah 3893, Saudi Arabia: ${ }^{b}$ Pharmaceutical \\ Chemistry Department, College of Pharmacy, King Saud University; 'Drug Bioavailability Laboratory, College of \\ Pharmacy, King Saud University; ${ }^{e}$ Drug Exploration \& Development Chair (DEDC), College of Pharmacy, King Saud \\ University; Riyadh 11451, Saudi Arabia: ${ }^{d}$ Research Unit, Univet Pharmaceutical Co.; Balteem 15324, Egypt: and \\ ${ }^{f}$ Applied Organic Chemistry Department, National Research Center; Dokki, Cairo 12622, Egypt.
}

Received July 1, 2011; accepted July 14, 2011; published online August 15, 2011

In continuation of our previous work, a novel series of steroid derivatives were synthesized and their androgen receptor (AR) antagonist activities and in vivo antiandrogenic properties were evaluated. Twenty-one heterocyclic derivatives containing a cyanopyrane ring fused to a steroidal moiety were conveniently synthesized and screened for their antagonistic, antiandrogen and prostate anticancer activities comparable to that of bicalutamide as the reference control. Some of the compounds exhibited better antagonistic, antiandrogen and prostate anticancer activities than the reference controls. Initially the acute toxicity of the compounds was assayed via the determination of their $\mathbf{L D}_{50}$. Synthetic steroidal structures fused to a substituted cyanopyrane ring seem to be a promising approach in the search for novel leads for potent antagonistic, antiandrogen and prostate anticancer agents.

Key words steroid; androgen; antagonist; antiandrogen; cancer

Prostate cancer has become the most common cancer among men, and the second leading cause of male cancer deaths in the United States. ${ }^{1)}$ Testosterone and $5 \alpha$-dihydrotestosterone are androgens that are required for the development of both the normal prostate and prostate cancer. ${ }^{2)}$ Androgens act through the androgen receptor (AR), which belongs to the steroid-receptor superfamily of ligand-dependent transcription factors. ${ }^{3,4)}$ Finasteride (Fig. 1) ${ }^{5}$ ) is known to inhibit Type $25 \alpha$-reductase and thus blocks the conversion of testosterone to dihydrotestosterone (DHT). The structural similarity of finasteride to DHT raises the possibility that finasteride may also interfere with the function of the androgen receptor (AR). Androgen ablation therapy remains the gold standard for the treatment of advanced prostate cancer, but unfortunately it is not curative, and eventually the disease will return as lethal castration-resistant prostate cancer (CRPC) ${ }^{6)}$ In our previous work, we found that certain substituted steroidal derivatives showed androgenic, anabolic, anticancer and anti-inflammatory activities. ${ }^{7-10)}$ Some new heterocyclic compounds containing nitrogen and sulfur atoms have been synthesized and used as antitumor, ${ }^{11)}$ antimicrobial, ${ }^{12-14)}$ and anti-inflammatory ${ }^{15)}$ agents. In this paper we describe the results of our studies on the synthesis

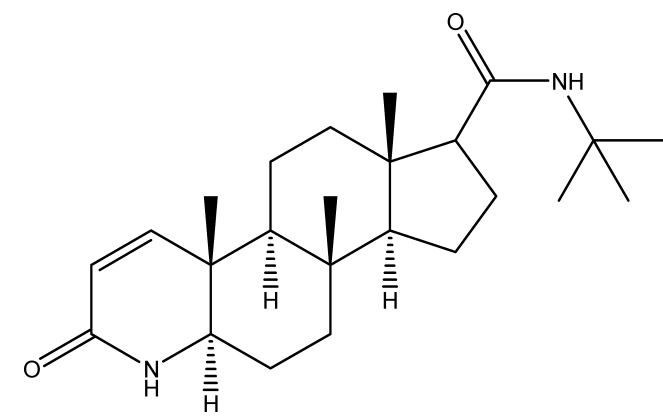

Fig. 1. Chemical Structure of Finasteride as a $5 \alpha$-Reductase Inhibitor and pharmacological evaluation of a series of steroid derivatives fused to a substituted cyanopyrane ring as antagonistic, antiandrogen and prostate anticancer agents.

\section{Results and Discussion}

Chemistry In continuation of our previous work, a series of steroid derivatives $\mathbf{1}-\mathbf{1 1}$ (Fig. 2) were synthesized in advance and screened as anti-inflammatory agents. ${ }^{16)}$ Herein, we used these compounds for evaluation as androgen receptor antagonists and anti-prostate cancer agents.

Additionally, some new derivatives were synthesized by reacting 3-hydroxy-10,13-dimethyl-16-(4-methylbenzylidene)dodecahydro- $1 H$-cyclopenta[ $a]$ phenanthren-17( $2 H)$-one $\mathbf{1 2}^{17,18)}$ with ethyl cyanoacetate in the presence of sodium ethoxide to afford the corresponding cyanopyrane 13 , which was then reacted with $p$-toluenesulfonylchloride to afford the corresponding cyclohexene derivative 14. Moffat oxidation of compound $\mathbf{1 3}$ gave the 3-oxo analogue 15 without affecting $\Delta^{5}$-ene. Oppenauer oxidation of $\mathbf{1 3}$ with aluminum isopropoxide resulted in 3-oxo-analogue with delocalization of $\Delta^{5}$-ene into $\Delta^{4}$-ene derivative 16. Modified Oppenauer oxidation $^{19)}$ of 13 afforded the corresponding $\Delta^{4,6}-3$-oxo-analogue 17 (Fig. 3).

Pharmacological Screening All the candidates were evaluated for their in vitro AR antagonistic activities using a reporter assay, and the resulting $\mathrm{IC}_{50}$ values are listed in Table 1. Also, evaluated was the in vivo anti-androgenic activity in Castrated Immature Rats, and the resulting \% inhibition values are listed in Table 2. In addition, all the analogues were evaluated by anti-prostate cancer screening antiandrogenic bioassay in human prostate cancer cells; the resulting $\mathrm{IC}_{50}$ values are listed in Table 3 .

The target compounds were tested for cytotoxicity against two human prostate cancer cell lines, LNCaP and PC-3. The $\mathrm{LNCaP}$ cell line is an androgen-dependent human prostate cancer cell line that expresses mutant AR, and the PC-3 cell 


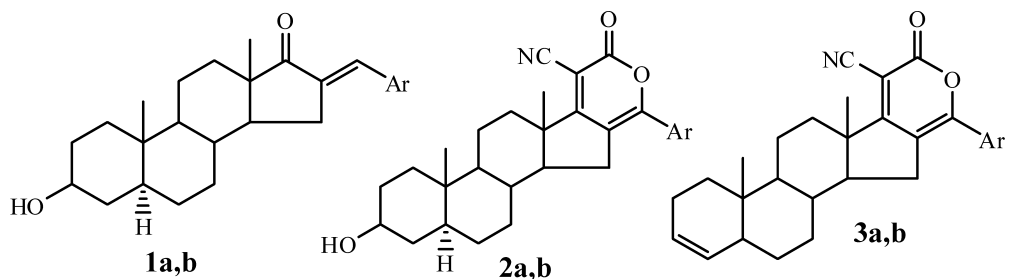<smiles>CC12CCC3C(CC[C@@H]4CC(=O)CCC34C)C1Cc1c2c([AlH2])oc(=O)c1C#N</smiles><smiles>CC12C=CC(=O)C=C1CCC1C2CCC2(C)c3c([AlH2])oc(=O)c(C#N)c3CC12</smiles>

$\mathbf{a}, \mathrm{Ar}=\mathrm{C}_{6} \mathrm{H}_{4}-\mathrm{F}(\mathrm{p}) ; \mathbf{b}, \mathrm{Ar}=\mathrm{C}_{6} \mathrm{H}_{4}-\mathrm{CH}_{3}(\mathrm{p})$<smiles></smiles>

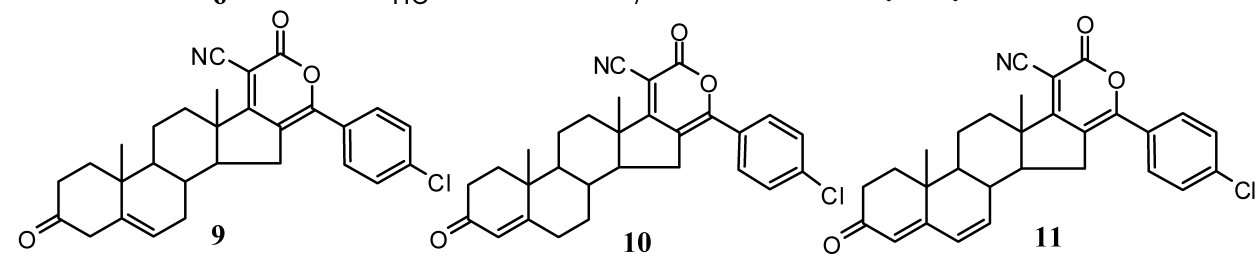

Fig. 2. Chemical Structures for the Compounds 1-11

Table 1. In Vitro Androgen Receptor (AR) Antagonistic Activities of Compounds $\mathbf{1}-\mathbf{1 7}$

\begin{tabular}{|c|c|c|}
\hline $\begin{array}{l}\text { Compound } \\
\text { No. }\end{array}$ & $\mathrm{IC}_{50}(\mu \mathrm{M})^{a)}$ & $\begin{array}{l}\text { Relative potency } \\
\text { to bicalutamide }\end{array}$ \\
\hline Bicalutamide & $0.890 \pm 0.31 \times 10^{-1}$ & 1 \\
\hline $1 \mathrm{a}$ & $0.741 \pm 0.63 \times 10^{-3}$ & 1.20 \\
\hline $1 b$ & $0.832 \pm 0.74 \times 10^{-3}$ & 1.07 \\
\hline $2 a$ & $0.411 \pm 0.33 \times 10^{-4}$ & 2.17 \\
\hline $2 \mathbf{b}$ & $0.432 \pm 0.44 \times 10^{-3}$ & 2.06 \\
\hline $3 a$ & $0.613 \pm 0.52 \times 10^{-3}$ & 1.45 \\
\hline $3 \mathbf{b}$ & $0.641 \pm 0.63 \times 10^{-3}$ & 1.39 \\
\hline $4 a$ & $0.195 \pm 0.19 \times 10^{-4}$ & 4.56 \\
\hline $4 b$ & $0.211 \pm 0.23 \times 10^{-4}$ & 4.22 \\
\hline $5 \mathbf{a}$ & $0.087 \pm 0.81 \times 10^{-5}$ & 10.23 \\
\hline $5 \mathbf{b}$ & $0.091 \pm 0.72 \times 10^{-5}$ & 9.78 \\
\hline 6 & $0.669 \pm 0.74 \times 10^{-3}$ & 1.33 \\
\hline 7 & $0.377 \pm 0.24 \times 10^{-4}$ & 2.36 \\
\hline 8 & $0.521 \pm 0.52 \times 10^{-3}$ & 1.71 \\
\hline 9 & $0.167 \pm 0.27 \times 10^{-4}$ & 5.33 \\
\hline 10 & $0.141 \pm 0.34 \times 10^{-5}$ & 6.31 \\
\hline 11 & $0.111 \pm 0.56 \times 10^{-5}$ & 8.02 \\
\hline 12 & $0.702 \pm 0.85 \times 10^{-3}$ & 1.27 \\
\hline 13 & $0.391 \pm 0.22 \times 10^{-4}$ & 2.27 \\
\hline 14 & $0.591 \pm 0.51 \times 10^{-3}$ & 1.50 \\
\hline 15 & $0.187 \pm 0.18 \times 10^{-3}$ & 4.76 \\
\hline 16 & $0.155 \pm 0.63 \times 10^{-5}$ & 5.74 \\
\hline 17 & $0.129 \pm 0.45 \times 10^{-5}$ & 6.90 \\
\hline
\end{tabular}

a) Compounds were tested for their ability to inhibit AR mediated transcriptional activation using a reporter assay. $\mathrm{IC}_{50}$ values were determined by six experimental runs in triplicate.
Table 2. In Vivo Antiandrogen Activities of Compounds 1-17

\begin{tabular}{ccc}
\hline \hline Compound No. & \% (inhibition) & $\mathrm{ED}_{50}(\mathrm{mg} / \mathrm{kg})$ \\
\hline Bicalutamide & $75.00 \pm 0.332$ & 1.60 \\
$\mathbf{1 a}$ & $76.81 \pm 0.252$ & 1.51 \\
$\mathbf{1 b}$ & $76.00 \pm 0.342$ & 1.58 \\
$\mathbf{2 a}$ & $83.77 \pm 0.534$ & 1.07 \\
$\mathbf{2 b}$ & $83.13 \pm 0.652$ & 1.09 \\
$\mathbf{3 a}$ & $80.19 \pm 0.423$ & 1.29 \\
$\mathbf{3 b}$ & $78.12 \pm 0.732$ & 1.31 \\
$\mathbf{4 a}$ & $85.88 \pm 0.272$ & 0.87 \\
$\mathbf{4 b}$ & $85.32 \pm 0.664$ & 0.98 \\
$\mathbf{5 a}$ & $88.00 \pm 0.663$ & 0.63 \\
$\mathbf{5 b}$ & $87.97 \pm 0.754$ & 0.65 \\
$\mathbf{6}$ & $77.71 \pm 0.342$ & 1.39 \\
$\mathbf{7}$ & $84.16 \pm 0.755$ & 1.00 \\
$\mathbf{8}$ & $82.71 \pm 0.743$ & 1.19 \\
$\mathbf{9}$ & $86.16 \pm 0.344$ & 0.77 \\
$\mathbf{1 0}$ & $87.45 \pm 0.745$ & 0.71 \\
$\mathbf{1 1}$ & $87.89 \pm 0.644$ & 0.66 \\
$\mathbf{1 2}$ & $77.11 \pm 0.262$ & 1.44 \\
$\mathbf{1 3}$ & $83.99 \pm 0.846$ & 1.01 \\
$\mathbf{1 4}$ & $81.21 \pm 0.335$ & 1.21 \\
$\mathbf{1 5}$ & $85.98 \pm 0.454$ & 0.81 \\
$\mathbf{1 6}$ & $87.16 \pm 0.845$ & 0.74 \\
$\mathbf{1 7}$ & $87.67 \pm 0.535$ & 0.69 \\
\hline & & \\
\hline
\end{tabular}




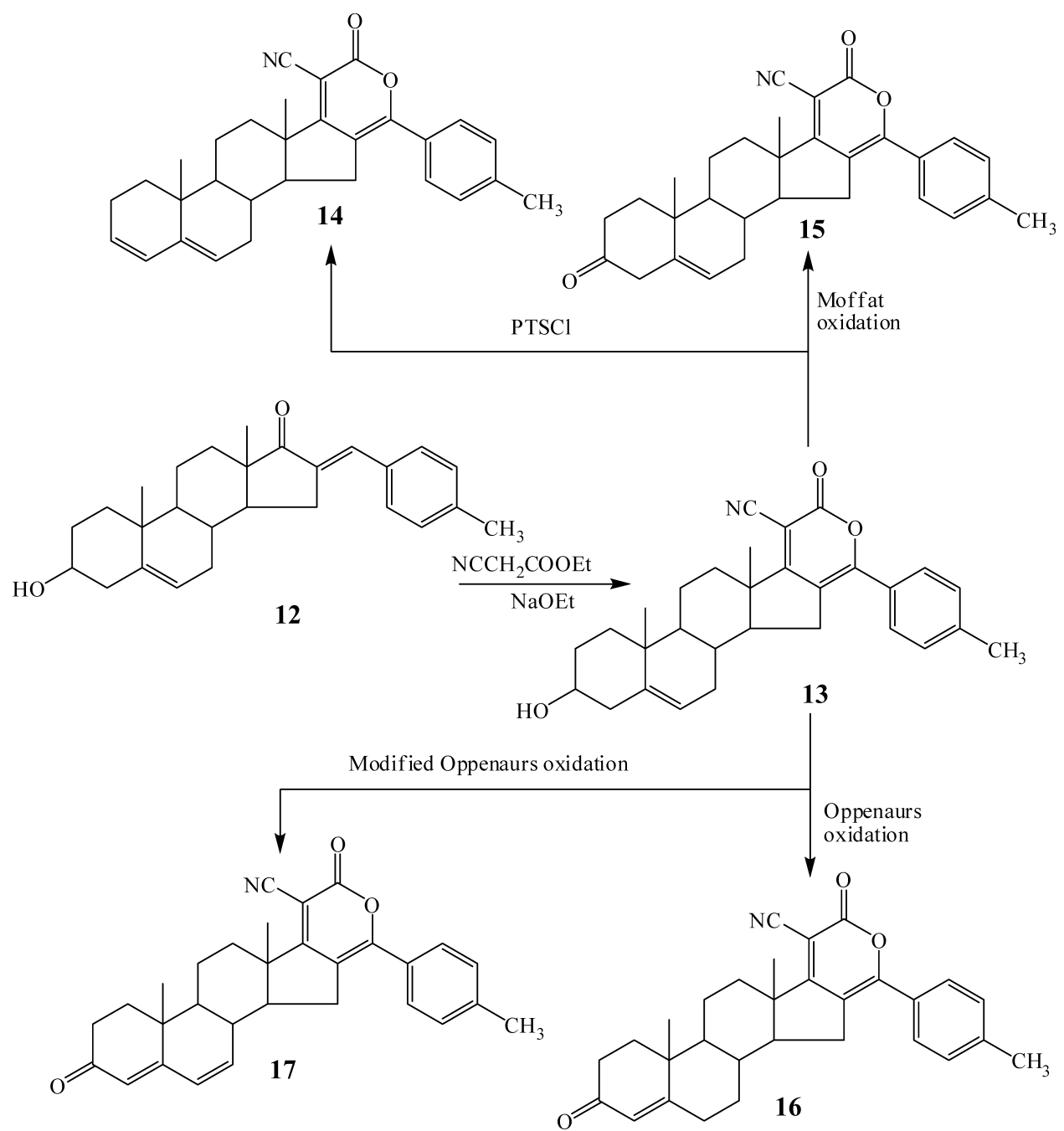

Fig. 3. Synthetic Routes for Compounds 13-17

Table 3. Anti-prostate Cancer Activities of Compounds 1-17

\begin{tabular}{ccc}
\hline \hline \multirow{2}{*}{$\begin{array}{c}\text { Compound } \\
\text { No. }\end{array}$} & \multicolumn{2}{c}{ Cytotoxicity $\mathrm{IC}_{50}(\mu \mathrm{M})$} \\
\cline { 2 - 3 } & PC-3 & $\mathrm{LNCaP}$ \\
\hline $\mathbf{1 a}$ & $0.722 \pm 0.44 \times 10^{-5}$ & $0.681 \pm 0.22 \times 10^{-5}$ \\
$\mathbf{1 b}$ & $0.733 \pm 0.53 \times 10^{-5}$ & $0.684 \pm 0.21 \times 10^{-5}$ \\
$\mathbf{2 a}$ & $0.584 \pm 0.73 \times 10^{-5}$ & $0.483 \pm 0.23 \times 10^{-5}$ \\
$\mathbf{2 b}$ & $0.595 \pm 0.31 \times 10^{-5}$ & $0.492 \pm 0.15 \times 10^{-5}$ \\
$\mathbf{3 a}$ & $0.646 \pm 0.42 \times 10^{-5}$ & $0.634 \pm 0.26 \times 10^{-5}$ \\
$\mathbf{3 b}$ & $0.677 \pm 0.33 \times 10^{-5}$ & $0.645 \pm 0.35 \times 10^{-5}$ \\
$\mathbf{4 a}$ & $0.507 \pm 0.36 \times 10^{-5}$ & $0.426 \pm 0.15 \times 10^{-5}$ \\
$\mathbf{4 b}$ & $0.517 \pm 0.43 \times 10^{-5}$ & $0.447 \pm 0.34 \times 10^{-5}$ \\
$\mathbf{5 a}$ & $0.217 \pm 0.12 \times 10^{-5}$ & $0.215 \pm 0.12 \times 10^{-5}$ \\
$\mathbf{5 b}$ & $0.227 \pm 0.43 \times 10^{-5}$ & $0.224 \pm 0.12 \times 10^{-5}$ \\
$\mathbf{6}$ & $0.687 \pm 0.64 \times 10^{-5}$ & $0.663 \pm 0.34 \times 10^{-5}$ \\
$\mathbf{7}$ & $0.537 \pm 0.62 \times 10^{-5}$ & $0.453 \pm 0.23 \times 10^{-5}$ \\
$\mathbf{8}$ & $0.617 \pm 0.61 \times 10^{-5}$ & $0.492 \pm 0.27 \times 10^{-5}$ \\
$\mathbf{9}$ & $0.487 \pm 0.54 \times 10^{-5}$ & $0.282 \pm 0.32 \times 10^{-5}$ \\
$\mathbf{1 0}$ & $0.446 \pm 0.62 \times 10^{-5}$ & $0.263 \pm 0.12 \times 10^{-5}$ \\
$\mathbf{1 1}$ & $0.415 \pm 0.31 \times 10^{-5}$ & $0.242 \pm 0.22 \times 10^{-5}$ \\
$\mathbf{1 2}$ & $0.714 \pm 0.54 \times 10^{-5}$ & $0.672 \pm 0.43 \times 10^{-5}$ \\
$\mathbf{1 3}$ & $0.543 \pm 0.82 \times 10^{-5}$ & $0.472 \pm 0.12 \times 10^{-5}$ \\
$\mathbf{1 4}$ & $0.623 \pm 0.51 \times 10^{-5}$ & $0.612 \pm 0.16 \times 10^{-5}$ \\
$\mathbf{1 5}$ & $0.493 \pm 0.25 \times 10^{-5}$ & $0.292 \pm 0.23 \times 10^{-5}$ \\
$\mathbf{1 6}$ & $0.473 \pm 0.73 \times 10^{-5}$ & $0.272 \pm 0.23 \times 10^{-5}$ \\
$\mathbf{1 7}$ & $0.423 \pm 0.23 \times 10^{-5}$ & $0.252 \pm 0.32 \times 10^{-5}$ \\
Bicalutamide & $0.822 \pm 0.11 \times 10^{-5}$ & $0.619 \pm 0.61 \times 10^{-5}$ \\
\hline
\end{tabular}

line is an androgen-independent human prostate cancer cell line that does not express functional AR. All the tested compounds exhibited significant cytotoxicity in either LNCaP or PC-3 cells.

Here we discuss the anti-androgenic activities of the tested compounds in vivo and in vitro, aiming to reach the proper mechanism of action. Firstly we discuss the in vitro AR antagonistic activities, followed by quantification of the in vivo anti-androgenic activities.

Anti-androgen ability plays an important role in lowering the androgen level, contributing to the healing from prostate cancer. Therefore we screened these anti-androgenic compounds for their anti prostate cancer activities, aimed at finding a new lead drug that combine both anti-androgenic and anti prostate cancer activity, a property long sought that can revolutionize of prostate cancer therapy.

First of all we have two categories of lead steroidal compounds, the $5 \alpha$-androstane-16-arylidenes $\mathbf{1 a}, \mathbf{b}$ (as bio-isoster for $5 \alpha$-DHT) and their unsaturated forms androst-5-en-16arylidenes $\mathbf{6}$ and 12, as AR antagonistic and anti-androgenic starting lead compounds. The descending order of activity is in the following order $\mathbf{6}, \mathbf{1 2}, \mathbf{1 a}$ and $\mathbf{b}$, which means that the unsaturated analogues are more active than the reduced $5 \alpha-\mathrm{H}$ analogues $\left(s p^{2}\right.$ atoms in the androsten cage provide more activity than the $s p^{3}$ atoms in the androstan cage). Also the at- 
taching groups that have an -I affect on the arylidene moiety play an important role in increasing the activity. Regarding anti-prostate cancer activity, the same occurred.

Fusion of a heterocyclic cyano pyrone ring system onto ring $\mathrm{D}$ in $[17,16-\mathrm{C}]$ resulted in increasing both AR antagonistic and anti-androgenic activities. Here the descending order of activity is $\mathbf{7}, \mathbf{1 3}, \mathbf{2} \mathbf{a}$ and $\mathbf{b}$, concluding that the heterocyclic fused ring systems play an important role in increasing the tested activities, but only to a certain extent. Regarding the anti-prostate cancer activity, the same thing occurred, but activity increases within 15-30\%. Removal of a molecule of water from ring A of the steroidal cage lead to formation of the androstene derivatives $\mathbf{3 a}, \mathbf{b}, \mathbf{8}$ and $\mathbf{1 4}$. The descending order of activity is $\mathbf{8}, \mathbf{1 4}, \mathbf{3 a}$ and $\mathbf{b}$. Here the activity is reduced by about $20-25 \%$ from their original derivatives ( $3 \beta$-hydroxyl essential for high anti-androgenic activity). Regarding the anti-prostate cancer activity, the same effects occurred but the activity decreased from $5-15 \%$.

Moffat oxidation of the $3 \beta$-hydroxyl in ring $\mathrm{A}$ of the steroidal cage leads to derivatives $4 \mathbf{a}, \mathbf{b}, 9$ and 15 that have 3fold higher activity than their starting $3 \beta$-hydroxy derivatives, and in the same time as the dehydrated derivatives. The order of activity is $\mathbf{9}, \mathbf{1 5}, \mathbf{4} \mathbf{a}$ and $\mathbf{b}$. Thus, the 3-oxo $\left(s p^{2}\right)$ function plays an important role in increasing anti-androgenic activity. Regarding the anti-prostate cancer activity, the same effects occurred but the increase in activity was to very limited extent, $12-22 \%$. Also, Oppenour oxidation of the $3 \beta$-hydroxyl in ring A of compounds 7 and 13 lead to compounds $\mathbf{1 0}$ and 16, which had about 2.5 times higher activity than their starting compounds confirming the essential role of the 3-oxo function in increasing the activity. The Oppenour oxidation products were more active than the normal Moffat oxidation products, leading to the conclusion that the enone system is more active than the normal 3 ketones.

Regarding anti-prostate cancer activity the same effects had occurred but to a very narrow extent. Dichlorodicyanoquinone (DDQ)-treatment of $\mathbf{4 a}, \mathbf{b}$ lead to the formation of the 1,4-diene-3-ones analogues $\mathbf{5 a}, \mathbf{b}$, the most potent compounds (i.e. increasing the $s p^{2}$ hybridization or the unsaturation or the degree of enone system that diminishes the probability of keto-enol form formation increases the antiandrogenic effects). Regarding anti-prostate cancer activity, the same effects occurred, but the activity increased 2-fold in PC-3, and to lower extent in LNCaP.

Modified Oppenour oxidation of both compounds 7 and 13 leads to the formation of derivatives $\mathbf{1 1}$ and $\mathbf{1 7}$ with 3-times higher activity, which also proves that the conjugation of enone is essential for high anti-androgenic activity, but that the conjugation in ring A provides the most active compounds. In conclusion, different types of oxidation leads to the following descending activity of the highly active antiandrogenic products 5a, b, 11, 17, 10 and $\mathbf{1 6 .}$

DDQ provides more active products than those resulting from modified Oppenour, while the latter provides more active products than normal Oppenour, whereas, Oppenour modified products provided more active products than Moffat. Regarding anti-prostate cancer activity the same effect occurred, but the activity increased 2-fold in LNCaP and to lower extent in PC-3.

Determination of Acute Toxicity ( $\left.\mathbf{L D}_{\mathbf{5 0}}\right) \quad$ The $\mathrm{LD}_{50}$ was determined using rats injected with different increasing doses
Table 4. Acute Toxicity $\left(\mathrm{LD}_{50}\right)$ of the Synthesized Compounds

\begin{tabular}{rc}
\hline \hline Compound No. & $\mathrm{LD}_{50}(\mathrm{mg} / \mathrm{kg})$ \\
\hline $\mathbf{2 a}$ & 4.186 \\
$\mathbf{2 b}$ & 2.514 \\
$\mathbf{3 a}$ & 1.711 \\
$\mathbf{3 b}$ & 1.880 \\
$\mathbf{4 a}$ & 3.813 \\
$\mathbf{4 b}$ & 2.681 \\
$\mathbf{5 a}$ & 2.684 \\
$\mathbf{5 b}$ & 2.751 \\
$\mathbf{7}$ & 3.111 \\
$\mathbf{8}$ & 1.250 \\
$\mathbf{9}$ & 3.111 \\
$\mathbf{1 0}$ & 2.868 \\
$\mathbf{1 1}$ & 3.068 \\
$\mathbf{1 3}$ & 2.962 \\
$\mathbf{1 4}$ & 1.750 \\
$\mathbf{1 5}$ & 3.055 \\
$\mathbf{1 6}$ & 2.821 \\
$\mathbf{1 7}$ & 2.870 \\
Prednisolone & 1.618 \\
\hline
\end{tabular}

of the synthesized compounds. The dose that killed $50 \%$ of the animals was calculated according to Austen and Brocklehurst. $^{20)}$ (Table 4).

\section{Conclusion}

All the tested compounds showed potent in vitro (via androgen receptor antagonist) and in vivo anti-androgenic oral activities. Also these compounds showed potent anti-prostate cancer activity. The descending order of activity is $\mathbf{5 a}, \mathbf{b}, \mathbf{1 1}$, 17, 10, 16, 9, 15, 4a, b, 7, 13, 2a, b, 8, 14, 3a, b, 6, 12, 1a, b.

Compound $\mathbf{5} \mathbf{a}$ had high potent in vitro AR antagonistic, in vivo anti-androgenic and anti-prostate cancer activities, while compound $\mathbf{1 2}$ had the least potent activities and in between, the descending order of potency is $\mathbf{5 a}, \mathbf{b}, \mathbf{1 1}, \mathbf{1 7}, \mathbf{1 0}, \mathbf{1 6}, \mathbf{9}$, $15,4 a, b, 7,13,2 a, b, 8,14,3 a, b, 6,12,1 a, b$. The reduction of a double bond decreases the activity, so we sought the double bonds essential for high activity, especially for C-4 where $s p^{2}$ hybridization is essential for high potency. Compounds $\mathbf{1 a}$ and $\mathbf{b}, \mathbf{6}, \mathbf{1 2}$, and $\mathbf{3 a}$ and $\mathbf{b}$ showed the least potency (the lowest is 1), which may be due to the $s p^{3}$ hybridization of C-4 reaching that of the 5- $\alpha$ androgenic characters. A heterocyclic ring system fused with ring $\mathrm{D}$ resulted in an increase in the activities. Replacement of the $s p^{3}$ of C-1 with $s p^{2}$ via oxidation of the $3-\beta$ hydroxyl into the 3-oxo function increases the anti-androgenic activity. The $s p^{2}$ hybridization for both C-3 and C-4 are essential for high activity. It is also possible that as the keto-enol form in ring $\mathrm{C}$ increases the activity decreases (compounds 10, 16 are more active than $4 \mathbf{a}, \mathbf{b})$. Next, we introduced a substitution group onto the phenyl ring; here the halide with a high inductive effect greatly increases the activity, higher than the methyl ones.

Structure-Activity Relationship Conjugated 1,4-diene3-one provided more activity than conjugated 4,6-diene-3one.

As the degree of unsaturation decreased led to the activity decreased.

Decreasing the degree of extended conjugation decreased activity (c.f., derivatives 10, 16 with extended conjugated enone systems were more active than 9, 15 which contained 
no enone extended conjugation).

3-Oxo function increased the activity more than the 3-hydroxyl one, while the latter increased the activity more than the dehydrated one.

A heterocyclic fused ring system markedly increased the activities.

Regarding substitution on the aryl moiety, both chloride and fluoride atoms provided higher activity than the methyl group.

\section{Experimental}

Chemistry Melting points were determined on open glass capillaries using an Electrothermal IA 9000 SERIES digital melting point apparatus (Electrothermal, Essex, U.K.), and are uncorrected. Elemental analyses were performed with all final compounds on an Elementar, Vario EL, Microanalytical Unit, National Research Centre, Cairo Egypt, and the results were found within $c a .0 .4 \%$ of the theoretical values. Analytical data were obtained from the Microanalytical Unit, Cairo University, Egypt. The IR spectra $(\mathrm{KBr})$ were recorded on a FT IR-8201 PC spectrophotometer (Shimadzu, Tokyo, Japan). The ${ }^{1} \mathrm{H}-\mathrm{NMR}$ spectra were measured with a JEOL FTGNMEX $270,270 \mathrm{MHz}$ instrument (JEOL, Tokyo, Japan) in DMSO- $d_{6}$, and chemical shifts were recorded in $(\delta, \mathrm{ppm})$ relative to tetramethylsilane (TMS). The mass spectra were run at $70 \mathrm{eV}$ with a Finnigan SSQ $7000 \mathrm{spec}-$ trometer (Thermo Electron Corporation, Madison, WI, U.S.A.) using EI, and the values of $\mathrm{m} / \mathrm{z}$ are indicated in Dalton. TLC (Silica gel, aluminum sheets $60 \mathrm{~F}_{254}$, Merck, Darmstadt, Germany) followed the reactions. The starting material 12 was prepared according to the published procedure. ${ }^{17,18)}$

2-Oxo-3-cyano-6-(4-chlorophenyl)androst-5-ene[17,16-c]pyran-3b-ol (13) A mixture of $12(3.90 \mathrm{~g}, 10 \mathrm{mmol})$ and ethyl cyanoacetate $(1.27 \mathrm{ml}$, $12 \mathrm{mmol}$ ) in $25 \mathrm{ml}$ sodium ethoxide ( $920 \mathrm{mg}$ sodium metal in $25 \mathrm{ml}$ absolute ethanol) was refluxed for $7 \mathrm{~h}$. The reaction mixture was poured into ice water, and the obtained solid was filtered off, washed with water, dried, and crystallized from ethanol to give the corresponding pyrano-steroidal derivatives 13. Yield $72 \%$; mp $210-212^{\circ} \mathrm{C}$; IR $\left(\mathrm{KBr}, \mathrm{cm}^{-1}\right)$ : 3524-3412 (OH) $2234(\mathrm{CN}), 1722(\mathrm{C}=\mathrm{O}) .{ }^{1} \mathrm{H}-\mathrm{NMR}\left(\mathrm{DMSO}-d_{6}\right) \delta: 0.77\left(\mathrm{~s}, 3 \mathrm{H}, \mathrm{CH}_{3}, \mathrm{C}-19\right)$, $0.82\left(\mathrm{~s}, 3 \mathrm{H}, \mathrm{CH}_{3}, \mathrm{C}-18\right), 0.88-1.05(\mathrm{~m}, 1 \mathrm{H}, \mathrm{CH}), 1.23-1.31(\mathrm{~m}, 4 \mathrm{H}$ $\left.2 \mathrm{CH}_{2}\right), 1.44-1.62\left(\mathrm{~m}, 6 \mathrm{H}, 3 \mathrm{CH}_{2}\right), 1.68-1.82\left(\mathrm{~m}, 2 \mathrm{H}, \mathrm{CH}_{2}\right), 1.96(\mathrm{~m}, 1 \mathrm{H}$, $\mathrm{CH}), 2.18\left(\mathrm{~s}, 3 \mathrm{H}, \mathrm{CH}_{3}\right), 2.28-2.48\left(\mathrm{~m}, 2 \mathrm{H}, \mathrm{CH}_{2}\right), 2.62(\mathrm{~m}, 1 \mathrm{H}, \mathrm{CH}), 3.64$ (m, $1 \mathrm{H}, 3 \alpha-\mathrm{CH}), 5.66(\mathrm{~m}, 1 \mathrm{H}, \mathrm{CH}$-olefinic, C-6), 7.32-7.44 (m, 4H, Ar-H), $10.46\left(\mathrm{~s}, 1 \mathrm{H}, \mathrm{OH}\right.$, exchangeable with $\left.\mathrm{D}_{2} \mathrm{O}\right)$. MS $m / z(\%)$ : $455\left(\mathrm{M}^{+}, 15\right)$, corresponding to the molecular formula $\mathrm{C}_{30} \mathrm{H}_{33} \mathrm{NO}_{3}$ and at $279(100$, base peak). Elemental analysis: Calcd: C, 79.09; H, 7.30; N, 3.07. Found: C, $79.00 ; \mathrm{H}, 7.24 ; \mathrm{N}, 3.00$

2-Ox0-3-cyano-6-(4-chlorophenyl)androst-3,5-diene[17,16-c]pyrane (14) A mixture of compound 13 (2.24 g, $5 \mathrm{mmol}), p$-toluene sulfonyl chloride $(0.4 \mathrm{~g}, 5 \mathrm{mmol})$, and triethylamine $(1 \mathrm{ml})$ in dry benzene $(15 \mathrm{ml})$ was refluxed for $2 \mathrm{~h}$. The solvent was evaporated under reduced pressure. The obtained residue was solidified with water and the solid formed was filtered off, washed with water, dried, then dissolved in dry benzene $(15 \mathrm{ml})$, and potassium tert-butoxide $(25 \mathrm{ml}, 0.5 \mathrm{~N}$, in dimethyl sulfoxide (DMSO)) was added. The reaction mixture was heated at $50{ }^{\circ} \mathrm{C}$ for $5 \mathrm{~h}$, The formed solid was filtered off and crystallized from dioxane to give the corresponding oxidized cyanopyrane derivative 14 . Yield $75 \% ; \mathrm{mp} 168-170{ }^{\circ} \mathrm{C}$; IR $(\mathrm{KBr}$, $\left.\mathrm{cm}^{-1}\right): 2238(\mathrm{CN}), 1726(\mathrm{C}=\mathrm{O}) .{ }^{1} \mathrm{H}-\mathrm{NMR}\left(\mathrm{DMSO}-d_{6}\right) \delta: 0.76\left(\mathrm{~s}, 3 \mathrm{H}, \mathrm{CH}_{3}\right.$, $\mathrm{C}-19), 0.82\left(\mathrm{~s}, 3 \mathrm{H}, \mathrm{CH}_{3}, \mathrm{C}-18\right), 0.88-0.96(\mathrm{~m}, 1 \mathrm{H}, \mathrm{CH}), 1.18-1.26(\mathrm{~m}$, $\left.4 \mathrm{H}, 2 \mathrm{CH}_{2}\right), 1.40-1.55\left(\mathrm{~m}, 4 \mathrm{H}, 2 \mathrm{CH}_{2}\right), 1.60-1.76\left(\mathrm{~m}, 2 \mathrm{H}, \mathrm{CH}_{2}\right), 1.92(\mathrm{~m}$ $1 \mathrm{H}, \mathrm{CH}), 2.16\left(\mathrm{~s}, 3 \mathrm{H}, \mathrm{CH}_{3}\right), 2.30-2.42\left(\mathrm{~m}, 2 \mathrm{H}, \mathrm{CH}_{2}\right), 2.58(\mathrm{~m}, 1 \mathrm{H}, \mathrm{CH})$ $5.28(\mathrm{~m}, 1 \mathrm{H}, \mathrm{CH}-$ olefinic, C-3), $5.54(\mathrm{~m}, 1 \mathrm{H}, \mathrm{CH}$-olefinic, C-4), $5.68(\mathrm{~m}$ 1H, CH-olefinic, C-6), 7.32-7.52 (m, 4H, Ar-H). MS m/z (\%): $437\left(\mathrm{M}^{+}\right.$, 24), corresponding to the molecular formula $\mathrm{C}_{30} \mathrm{H}_{31} \mathrm{NO}_{2}$ and 277 (100, base peak). Elemental analysis: Calcd: C, 82.35; H, 7.14; N, 3.20. Found: C, $82.30 ; \mathrm{H}, 7.08 ; \mathrm{N}, 3.12$

2-Oxo-3-cyano-6-(4-chlorophenyl)androst-5-ene[17,16-c]pyran-3-one (15) The appropriate compound $\mathbf{1 3}(0.92 \mathrm{~g}, 2 \mathrm{mmol})$ was dissolved in a mixture of benzene $(3 \mathrm{ml})$, dimethylsulphoxide $(3 \mathrm{ml})$, pyridine $(0.16 \mathrm{ml})$, and trifluoroacetic acid (TFA, $0.08 \mathrm{ml})$. Dicyclohexylcarbodiimide $(1.24 \mathrm{~g}$, $6 \mathrm{mmol}$ ) was then added and the reaction mixture was kept overnight at room temperature. Ether $(50 \mathrm{ml})$ was added, followed by oxalic acid $(0.54 \mathrm{~g}$, $6 \mathrm{mmol})$ in methanol $(50 \mathrm{ml})$. After $30 \mathrm{~min}$, water $(50 \mathrm{ml})$ was added and the obtained dicyclohexyl urea was removed by filtration. The filtrate was extracted with ether, washed with $5 \%$ sodium bicarbonate, then with water The ethereal solution was dried over anhydrous sodium sulphate and evapo- rated under reduced pressure. The formed residue was finally crystallized from acetic acid/water to give the corresponding oxo-compound $\mathbf{1 5}$. Yield $58 \%$; mp 184-86 ${ }^{\circ} \mathrm{C}$; IR $\left(\mathrm{KBr}, \mathrm{cm}^{-1}\right): 2235(\mathrm{CN}), 1725(\mathrm{C}=\mathrm{O}) .{ }^{1} \mathrm{H}-\mathrm{NMR}$ (DMSO- $\left.d_{6}\right) \delta: 0.75\left(\mathrm{~s}, 3 \mathrm{H}, \mathrm{CH}_{3}, \mathrm{C}-19\right), 0.79\left(\mathrm{~s}, 3 \mathrm{H}, \mathrm{CH}_{3}, \mathrm{C}-18\right), 0.96-1.02$ $(\mathrm{m}, 1 \mathrm{H}, \mathrm{CH}), 1.26-1.32\left(\mathrm{~m}, 4 \mathrm{H}, 2 \mathrm{CH}_{2}\right), 1.44-1.62\left(\mathrm{~m}, 6 \mathrm{H}, 3 \mathrm{CH}_{2}\right), 1.68-$ $1.92\left(\mathrm{~m}, 2 \mathrm{H}, \mathrm{CH}_{2}\right), 2.10(\mathrm{~m}, 1 \mathrm{H}, \mathrm{CH}), 2.25\left(\mathrm{~s}, 3 \mathrm{H}, \mathrm{CH}_{3}\right), 2.30-2.42(\mathrm{~m}$, $\left.2 \mathrm{H}, \mathrm{CH}_{2}\right), 2.47(\mathrm{~m}, 1 \mathrm{H}, \mathrm{CH}), 5.56(\mathrm{~m}, 1 \mathrm{H}, \mathrm{CH}$-olefinic, C-6), 7.22-7.35 $(\mathrm{m}, 4 \mathrm{H}, \mathrm{Ar}-\mathrm{H})$. MS $m / z(\%): 453\left(\mathrm{M}^{+}, 32\right)$, corresponding to the molecular formula $\mathrm{C}_{30} \mathrm{H}_{31} \mathrm{NO}_{3}$ and at 229 (100, base peak). Elemental analysis: Calcd: C, 79.44; H, 6.89; N, 3.09. Found: C, 79.36; H, 6.82; N, 3.00.

2-Oxo-3-cyano-6-(4-chlorophenyl)androst-4-ene[17,16-c]pyran-3-one (16) (Oppenauer Oxidation) To a solution of compound $13(6.9 \mathrm{mmol})$ in a mixture of cyclohexanone $(50 \mathrm{ml}) /$ dry benzene $(45 \mathrm{ml})$, freshly distilled aluminum isopropoxide $(2 \mathrm{~g}, 9.7 \mathrm{mmol})$ in benzene $(5 \mathrm{ml})$ was added. The reaction mixture was refluxed for $16 \mathrm{~h}$. The reaction mixture was treated dropwise with water $(4 \mathrm{ml})$ and the precipitated aluminum salt was collected by filtration. The filtrate was evaporated under reduced pressure and the obtained residue was crystallized from methanol to give the corresponding oxidized derivative 16. Yield $65 \%$; $\mathrm{mp} 142-143^{\circ} \mathrm{C}$; IR $\left(\mathrm{KBr}, \mathrm{cm}^{-1}\right)$ : 2236 $(\mathrm{CN}), 1758\left(\mathrm{C}=\mathrm{O}\right.$, enone), $1726\left(\mathrm{C}=\mathrm{O}\right.$, ketone). ${ }^{1} \mathrm{H}-\mathrm{NMR}$ (DMSO- $\left.d_{6}\right) \delta$ : 0.75 (s, 3H, $\left.\mathrm{CH}_{3}, \mathrm{C}-19\right), 0.80$ (s, 3H, $\left.\mathrm{CH}_{3}, \mathrm{C}-18\right), 0.98-1.10$ (m, 1H, CH), $1.24-1.32\left(\mathrm{~m}, 4 \mathrm{H}, 2 \mathrm{CH}_{2}\right), 1.45-1.55\left(\mathrm{~m}, 4 \mathrm{H}, 2 \mathrm{CH}_{2}\right), 1.62-1.75(\mathrm{~m}, 4 \mathrm{H}$ $\left.2 \mathrm{CH}_{2}\right), 1.82(\mathrm{~m}, 1 \mathrm{H}, \mathrm{CH}), 1.88-2.05\left(\mathrm{~m}, 2 \mathrm{H}, \mathrm{CH}_{2}\right), 2.22\left(\mathrm{~s}, 3 \mathrm{H}, \mathrm{CH}_{3}\right)$, 2.32-2.42 (m, 1H, CH), 5.73 (s, 1H, CH-olefinic, C-4), 7.23-7.38 (m, 4H, Ar-H). MS $m / z(\%): 453\left(\mathrm{M}^{+}, 100\right.$, base peak), corresponding to the molecular formula $\mathrm{C}_{30} \mathrm{H}_{31} \mathrm{NO}_{3}$. Elemental analysis: Calcd: C, 79.44; H, 6.89; $\mathrm{N}$, 3.09. Found: C, 79.35; H, 6.84; N, 3.01.

3-Oxo-3-cyano-6-(4-chlorophenyl)androst-4,6-diene[17,16-c]pyrane-3one (17) The compound was prepared according to the Wettstein method (Modified Oppenauer) ${ }^{19,21)}$ using compound $\mathbf{1 3}$ as the starting material. Yield $68 \%$; mp $152-153^{\circ} \mathrm{C}\left(\mathrm{AcOH} / \mathrm{H}_{2} \mathrm{O}\right)$; IR $\left(\mathrm{KBr}, \mathrm{cm}^{-1}\right): 2236(\mathrm{CN})$, $1767\left(\mathrm{C}=\mathrm{O}\right.$, enone), $1724\left(\mathrm{C}=\mathrm{O}\right.$, ketone). ${ }^{1} \mathrm{H}-\mathrm{NMR}$ (DMSO- $\left.d_{6}\right) \delta: 0.76(\mathrm{~s}$, $\left.3 \mathrm{H}, \mathrm{CH}_{3}, \mathrm{C}-19\right), 0.84$ (s, 3H, $\left.\mathrm{CH}_{3}, \mathrm{C}-18\right), 1.02-1.12(\mathrm{~m}, 1 \mathrm{H}, \mathrm{CH}), 1.24$ $1.34\left(\mathrm{~m}, 2 \mathrm{H}, \mathrm{CH}_{2}\right), 1.43-1.54\left(\mathrm{~m}, 2 \mathrm{H}, \mathrm{CH}_{2}\right), 1.64-1.76\left(\mathrm{~m}, 4 \mathrm{H}, 2 \mathrm{CH}_{2}\right)$, $1.79(\mathrm{~m}, 1 \mathrm{H}, \mathrm{CH}), 1.82-2.04\left(\mathrm{~m}, 2 \mathrm{H}, \mathrm{CH}_{2}\right), 2.15\left(\mathrm{~s}, 3 \mathrm{H}, \mathrm{CH}_{3}\right), 2.28-2.42$ $(\mathrm{m}, 1 \mathrm{H}, \mathrm{CH}), 5.77$ (s, 1H, CH-olefinic, C-4), 6.18 (m, 1H, CH-olefinic, C-7), 6.74 (d, 1H, CH-olefinic, C-6), 7.23-7.28 (m, 4H, Ar-H). MS m/z (\%): 451 $\left(\mathrm{M}^{+}, 18\right)$, corresponding to the molecular formula $\mathrm{C}_{30} \mathrm{H}_{29} \mathrm{NO}_{3}$ and at 292 (100, base peak). Elemental analysis: Calcd: C, 79.80; H, 6.47; N, 3.10. Found: C, 79.75; H, 6.40; N, 3.04

Pharmacology Screening. Evaluation of Transcriptional Activity for Human Androgen Receptor ${ }^{22}$ (a) Establishment of Chinese Hamster Ovary (CHO) Cells Stably Transfected with Human Androgen Receptor Gene and MMTV-Luciferase Reporter Gene or SV40-Luciferase Gene $\mathrm{CHO}$ cells were maintained in alpha-modified Eagle's medium supplemented with $10 \%$ fetal bovine serum (FBS). The culture medium of neomycin-resistant clone cells was supplemented with $10 \%$ dextran-coated charcoal-stripped FBS (DCC-FBS) and $500 \mu \mathrm{g} / \mathrm{ml}$ of neomycin. The CHO cells were transfected at $40-70 \%$ confluence in $10-\mathrm{cm}$ petri dishes with a total of $20 \mu \mathrm{g}$ DNA (pMAMneoLUC; MMTV-luciferase reporter plasmid and pSG5-hAR; human androgen receptor expression plasmid, or SV40LUC; SV40-luciferase reporter plasmid containing neomycin resistant gene) by calcium phosphate mediated transfection. The stable transfected cells were selected in the culture medium supplemented with neomycin. The selected clone was designated as AR/CHO\#3 (human AR gene and MMTVluciferase reporter gene integrated $\mathrm{CHO}$ cell) or SV/CHO\#10 (SV-40luciferase reporter gene integrated $\mathrm{CHO}$ cell), respectively.

(b) Activities of the Tested Compounds to Inhibit Androgen Receptor Mediated Transcription Induced by DHT (AR Antagonistic Activity) The stable transfected $\mathrm{AR} / \mathrm{CHO} \# 3$ or $\mathrm{SV} / \mathrm{CHO} \# 10$ cells were plated onto 96-well luminoplates (Packard) at a density of $2 \times 10^{4}$ cells/well, respectively. Four to eight hours later, the medium was changed to a medium containing DMSO, $0.3 \mathrm{~nm}$ of DHT, or $0.3 \mathrm{~nm}$ of DHT, and the tested compound. At the end of incubation, the medium was removed and the cells were lysed with $20 \mu$ l of lysis buffer [ $25 \mathrm{~mm}$ Tris- $\mathrm{HCl}$ (pH 7.8), 2 mM dithiothreitol, 2 mM 1,2-cyclo-hexanediamine-tetraacetic acid, $10 \%$ glycerol and $1 \%$ Triton $\mathrm{X}-100]$. Luciferase substrate $\left[20 \mathrm{~mm}\right.$ Tris- $\mathrm{HCl}(\mathrm{pH} 7.8), 1.07 \mathrm{~mm}\left(\mathrm{MgCO}_{3}\right)_{4}$ $\mathrm{Mg}-(\mathrm{OH})_{2} \cdot 5 \mathrm{H}_{2} \mathrm{O}, 2.67 \mathrm{~mm} \quad \mathrm{MgSO}_{4} \cdot 7 \mathrm{H}_{2} \mathrm{O}, 0.1 \mathrm{~mm}$ ethylenediaminetetraacetic acid (EDTA), $33.3 \mathrm{~mm}$ dithiothreitol, $0.27 \mathrm{~mm}$ CoA, $0.47 \mathrm{~mm}$ luciferin, $0.53 \mathrm{~mm}$ ATP] was added, and luciferase activity was measured with a ML3000 luminometer (Dynatech Laboratories). AR antagonistic activities were calculated by the formula below:

AR antagonistic activity $(\%)=100(I-X) /(I-B)$ 
I: (luciferase activity of $\mathrm{AR} / \mathrm{CHO} 33$ )/(luciferase activity of $\mathrm{SV} / \mathrm{CHO \# 10)}$ in the presence of $0.3 \mathrm{~nm}$ of DHT,

$B$ : (luciferase activity of $\mathrm{AR} / \mathrm{CHO} \# 3$ )/(luciferase activity of $\mathrm{SV} / \mathrm{CHO} \# 10$ ) in the presence of DMSO,

$X$ : (luciferase activity of $\mathrm{AR} / \mathrm{CHO} \# 3$ )/(luciferase activity of SV/CHO\#10) in the presence of $0.3 \mathrm{~nm}$ of DHT and the tested compound.

The concentration of compounds showing $50 \%$ AR antagonistic activity, or $\mathrm{IC}_{50}$ values, were obtained by nonlinear analysis using a statistical analysis system (SAS).

In Vivo Evaluation of Antiandrogenic Activities in Castrated Immature Rats ${ }^{22}$ Andorgen treated male Wistar rats were obtained from the Animal House Colony, Research Institute of Ophthalmology, Giza, Egypt. Prepubertal male rats aged 3 weeks were castrated by the scrotal route under ether anesthesia. Three days after the castration, testosterone propionate (TP, $0.5 \mathrm{mg} / \mathrm{kg}$, subcutaneously (s.c.)) was administered once daily for $5 \#$ days, alone or in combination with the tested compound $(10-30 \mathrm{mg} / \mathrm{kg}$, per os (p.o.)). TP was dissolved in cotton seed oil containing 5\% ethanol. The tested compound was suspended with $0.5 \%$ methylcellulose. The rats were sacrificed by excessive chloroform anesthesia $6 \mathrm{~h}$ after final dosing, and both their ventral prostates and seminal vesicles-coagulate glands were removed and weighed. The antiandrogenic activity was expressed as a percentage of inhibition of the TP effect (TP-treated rats were arbitrarily assigned a value of $0 \%$ and vehicle-treated rats a value of $100 \%$ ).

Anti-prostate Cancer Screening Antiandrogenic Bioassay in Human Prostate Cancer Cells ${ }^{23}$ ) Human prostate cancer LNCaP and PC-3 cells were maintained in RPMI medium and Dulbecco's minimum essential medium (DMEM), respectively. Both media were supplemented with penicillin $(25 \mathrm{units} / \mathrm{ml})$, streptomycin $(25 \mu \mathrm{g} / \mathrm{ml})$, and $10 \%$ fetal calf serum. For the androgen receptor transactivation assay, an androgen-dependent reporter gene transcription test was employed as the primary screening for potential antiandrogen identification.

This assay was first performed in LNCaP cells, which express a clinically relevant mutant AR. Once anti-androgenic activity was detected in the LNCaP AR transactivation assay, compounds were re-examined for their potential activity against wild type AR. Wild type AR transactivation assay was performed in PC-3 host cells, which lack an endogenous, functional AR. The method and conditions of cell and gene transfection have been described previously. In brief, cells were plated in 24-well tissue culture dishes for 24 (PC-3 cells) or 48 (LNCaP cells) h prior to transfection. Subsequently, LNCaP cells were transfected with a reporter gene, MMTV-luciferase, which contains a MMTV-LTR promoter and a androgen receptor binding element, and PRL-SV40, which served as an internal control for transfection efficiency. PC-3 cells were transfected with a wild type AR expression plasmid, pSG5AR, in addition to the above-mentioned MMTV-luciferase reporter gene and PRL-SV40 internal control. SuperFect (Qiagen, Chatsworth, CA, U.S.A.) was employed as the transfection reagent following the manufacturer's recommendations. At the end of a 5-h transfection, the medium was changed to DMEM or RPMI supplemented with $10 \%$ charcoal dextranstripped, i.e. androgen-depleted, serum. After $24 \mathrm{~h}$, the cells were treated with $1 \mathrm{~nm}$ of DHT and/or test compounds at the designated concentration for another $24 \mathrm{~h}$. The cells were harvested for luciferase activity assay using the Dual Luciferase Assay System (Promega, Madison, WI, U.S.A.). The de- rived data were expressed as relative luciferase activity normalized to the internal luciferase control. Cells cultured in medium containing DHT (androgen), as a positive control, induced a marked increase in reporter gene expression. Test compounds capable of significantly suppressing this DHTinduced reporter gene expression were identified as potential antiandrogens.

Acknowledgement The authors extend their appreciation to the Deanship of Scientific Research at King Saud University for funding this work through the research group project No. RGP-VPP-099.

\section{References}

1) Landis S. H., Murray T., Boldon S., Wingo P. A., CA Cancer J. Clin., 49, 8-31 (1999).

2) Cunha G. R., Donjacour A. A., Cooke P. S., Mee S., Bigsby R. M., Higgins S. J., Sugimura Y., Endocr. Rev., 8, 338-362 (1987).

3) Vans R. M., Science, 240, 889-895 (1988)

4) Beato M., Cell, 56, 335-344 (1989).

5) Wu Y., Chhipa R. R., Zhang H., Ip C., Cancer Biol. Ther, 11, (2011) in print. PMID: 21386657 [PubMed-as supplied by publisher].

6) Sadar M. D., Cancer Res., 71, 1208-1213 (2011).

7) Amr A. E., Mohamed A. M., Mohamed S. F., Abdel-Hafez N. A., Hammam A. G., Bioorg. Med. Chem., 14, 5481-5488 (2006).

8) Amr A. E., Abdulla M. M., Indian J. Heterocycl. Chem., 12, 129-134 (2002).

9) Amr A. E., Abdel-Latif N. A., Abdalla M. M., Bioorg. Med. Chem., 14, 373-384 (2006).

10) Amr A. E., Ali K. E., Abdalla M. M., Europ. J. Med. Chem., 44, 901907 (2009)

11) Amr A. E., Abou-Ghalia M. H., Amino Acids, 26, 283-289 (2004).

12) Amr A. E., Mohamed A. M., Ibrahim A. A., Z. Naturforsch., 58b, $861-868$ (2003).

13) Amr A. E., Abdel-Salam O. I., Attia A., Stibor I., Collect. Czech. Chem. Commun., 64, 288-298 (1999).

14) Attia A., Abdel-Salam O. I., Amr A. E., Stibor I., Budesinsky M., Egypt. J. Chem., 43, 187-201 (2000).

15) Abou-Ghalia M. H., Amr A. E., Abdalah M. M., Z. Naturforsch., 58b, 903-910 (2003).

16) Amr A. E., Abdulla M. M., Arch. Pharm. Chem. Life Sci., 339, 88-95 (2006).

17) Amr A. E., Hegab M. I., Ibrahiem A. A., Abdulla M. M., Monatsh. Chem., 134, 1395-1409 (2003).

18) Ghilezan I., Jones E. R., Meakins G. D., Miners J. O., J. Chem. Soc., Perkin 1, 12, 1350-1351 (1976).

19) Wettstein A., Schmidlin J., Helv. Chim. Acta, 43, 829-836 (1960).

20) Austen K. F., Brocklehurst W. E., J. Exp. Med., 113, 521—524 (1961).

21) Herrmann F., Lindemann A., Gamss J., Mertelsmann R., Eur. J. Immunol., 20, 2513-2517 (1990).

22) Kinoyama I., Taniguchi N., Kawaminami E., Nozawa E., Koutoku H., Furutani T., Kudoh M., Okada M., Chem. Pharm. Bull., 53, 402-409 (2005).

23) Lina L., Shi Q., Nyarko A. K., Bastow K. F., Wu C. C., Su C. Y., Shih C. C. Y., Lee K. H., J. Med. Chem., 49, 3963-3972 (2006) 